\title{
Reading Development during Early Elementary School Years in Young English Language Learners
}

\author{
Hsin-Hui $\operatorname{Lin}^{1^{*}}$, Liping Wei ${ }^{1}$, and Mei-Chih Wang ${ }^{2}$ \\ ${ }^{1}$ Department of Teacher Leadership and New Literacies, University of Houston - Victoria, United States \\ ${ }^{2}$ Department of Urban Education, University of Houston-Downtown, United States \\ Email: linh@uhv.edu
}

\begin{abstract}
This national study investigates the depth of reading development in kindergarten and first grade by analyzing the students' emerging skills on early reading proficiencies. T-tests conducted will test the differences in reading Item Response Theory (IRT) scores between the English Language Learners (ELL) and the English Only Learners (EOL) groups. Children's learning outcomes in reading performance and proficiencies have shown differences between the EOLs and ELLs groups. The EOL children did better than ELL children in development of reading IRT scale scores and reading proficiencies in all three rounds of assessments. The reading gap seemed to widen between the groups as the children finished first grade. Early intervention in reading will help ELL students catch up with the learning pace and provide them with the opportunities to maximize student development in reading.
\end{abstract}

Keywords: Academic performance, child development, literacy, kindergarten, second language reading

\section{Introduction}

There are large bodies of research studies that investigate early literacy development with first languages. "However, relatively little research documents early literacy development in English as a second language, particularly among students who have not had literacy instruction in their first language" (Peregoy \& Boyle, 2013, p. 174). Reading is a vital source of comprehensible input, through which, second language acquisition takes place, according to Krashen (2004). Reading skills lay the foundation for academic learning. For the first two years of school, children learn to read, somewhere in the second grade, children start to shift from reading to learning. Thus, early reading development is critical for future successful academic learning.

\section{$2 \quad$ Literature Review}

\subsection{Language Development}

A child's first language acquisition starts at birth and continues to develop through 12 years of age, with continuous acquisition of new vocabularies throughout a lifetime (de Villiers \& de Villiers, 1979). Students who have learned and used English from early childhood are English Only Learners (EOL), while other students whose first languages are not English and speak English only as a second language are English Language Learners (ELL). Acquiring a second language often is a challenge. Some people believe it is easier for young children, but researchers who study second language acquisition found it is a very complex process and occurs over a long lengthy period of time (McLaughlin, 1984).

\subsection{Student Population Changed in the U.S.}

In the U.S., the percentage of ELL students enrolled in public schools has continued to rise dramatically over the past decade. Several southern states have experienced 300 to 400 percent increases of ELL students. Some school districts now have more than $50 \%$ of the preschool population of students who come from non-English-Speaking homes (Espinosa, 2008). In the years of 2002-2003, there were about 
4.1 million $(8.7 \%)$ of ELL students, in the United S. A recent record showed that ELL students accounted for $9.2 \%$ (an estimated 4.4 million) of the total student population in the 2012-13 school year (Kena et al., 2015).

\subsection{Teaching Reading for Young Children}

The phonemic instruction is used with the beginning English readers (Ehri, 2003). This type of instruction includes phonemic awareness, phonics, fluency, reading comprehension, and vocabulary. The phonemic instruction helps students with word recognition but also reading comprehension (Ehri, 2003). Through phonemic instruction, children acquire phonemic awareness, use letter -sound relationships to read, spell words, and learn reading skills (Ehri, 2003).

Two early reading skills, phonemic awareness and letter knowledge, were found to be the best school entry predictors in regarding how well children learn to read during kindergarten and first grade (Share, Jorm, Matthews \& Maclean, 1984). In addition, risk factors associated with young readers in the first two years of school were poor letter knowledge, poor phonemic awareness, poor reading skills, or enrollment in low achieving schools (Ehri, 2003). Except for enrollment in low achieving schools, the other three factors involved phonemic instruction. Poor readers who fail to master these reading skills had difficulties on decoding words (Rack, Snowling, \& Olson, 1992). When voung children fall behind in developing early reading skills, they would be at greater risk for future reading difficulties (Ehri, 2003).

\subsection{Reading Development in Young Children}

In children's early reading development, vocabulary knowledge serves as a major building block and provides the foundation for learning to decode and comprehend text (Se'ne'chal, LeFevre, Thomas, \& Daley, 1998). The speed in which young children accumulated the vocabularies is fast. Researchers indicated that between 18 months and 6 years of age, children learned approximately one new word in every hour when awake (Gelman \& Kalish, 2006). When children entered first grade, the children gained about 14,000 words (Clak, 1995).

\subsection{ELL Students' Reading Development}

While EOL learn to read primarily utilizing phonics skills, putting sound together and matching words in speaking vocabularies (National Reading Panel, 2000), researchers suggested that this might not be the path how ELL students develop English reading ability (Slavin \& Cheung, 2004). ELL students often arrived at school with insufficient vocabulary knowledge to support literacy acquisition (Moats, 2001) and were at risk of poor reading outcomes (Kena et al., 2015). In one study of Head Start, the Families and Children Experiences Survey (FACES) found that compared to the EOL children, Spanishspeaking Head Start and English-proficient bilingual children's language and literacy abilities were below the age expectations when entering kindergartens (Hammer, Lawrence, \& Miccio 2007; National Institutes of Health, 2000; Zill et al., 2003).

With limited language capability, the ELL students might not be able to communicate fluently or learn effectively in English. Children often struggled to become fluent in English but fell behind on academic achievement. For example, it has been reported that ELL students showed reading proficiency levels that were 23 to $30 \%$ points lower than EOL students (NCES 2014). The poor academic performance often associates with the difficulties of student retention. The ELL students' school dropout rates are almost double that of the EOLs (Espinosa, 2008).

Through teaching ELL students, early childhood professionals recognize that in order to provide an appropriate language environment, special accommodations must be adopted to meet ELL students' needs (Lake \& Pappamihiel, 2003). Research findings suggest that ELL children can learn social English within a few years. However, many ELL children may take five to eight years of English instruction to reach academic proficiency (Cummins, 1991; Lake \& Pappamihiel, 2003; Santos de Barona \& Barona, 1991). 


\subsection{ELL Students' Reading Performance}

The results of national testing conducted in 2005 showed that nearly half $(46 \%)$ of $4^{\text {th }}$ grade ELL students' category scored "below basic" in mathematics in 2005 - the lowest level possible. Nearly three quarters $(73 \%)$ scored below basic in reading. In addition, the National Assessment of Educational Progress (NAEP) records revealed that from 2002 to 2011, $4^{\text {th }}$ grade ELL students had lower reading scores than non-ELL students. In 2011, between non-ELL and ELL $4^{\text {th }}$ grade students, the achievement gap was 36 points. This achievement gap has remained consistent since 2002 (Aud et al., 2013). Results from the NAEP 2005 report indicated that nearly $73 \%$ of ELL students in the $4^{\text {th }}$ grade scored below basic requirements in reading. When compared to white counterparts, $47 \%$ of ELL students were behind in reading (Fry, 2007).

As for the older students, the analysis of national standardized testing scores shows that about $51 \%$ of $8^{\text {th }}$ grade ELL students are behind whites in reading and math, meaning that the scores for one out of every two will have to improve for the group to achieve parity. In the $4^{\text {th }}$ grade, $35 \%$ of ELL students are behind in math and $47 \%$ are behind in reading when compared with white counterparts. The report also compares scores for ELL students to those of black and Hispanics students and finds smaller, but still substantial gaps (Perie, Grigg, \& Donahue, 2005).

The fourth grade is the earliest point at which the National Report Card tracks students' academic performance. Additionally, under the United States federal "No Child Left Behind Act", the U.S. Department of Education requires each state set a standard for accountability and to determine the methods and procedures for measuring students' adequate yearly progress (AYP). Reading and math are the two main content areas. The earliest grade level on the state test is third grade.

The reading development in kindergarten and first grade has a great impact on students' reading achievement. When children fell behind in early grades, kindergarten and first grade, students got further behind throughout grade school (Grossen, 1997). Thus using students' third grade reading AYP results to monitor students' reading development is not only ineffective, but also puts students at greater risk for academic failures. Children's reading development starts in kindergarten. It is important to track in the earliest stage how ELL develop English skills.

\subsection{Purpose}

It was not clear how much progress ELL students made on reading development in the early elementary school years. In order to learn more about the impacts of an ELL background on children, it is important to investigate children's reading development throughout kindergarten and first grade in addition to later years. Two main issues to address are:

(1) How did the student overall reading development, reading knowledge, and skills change during kindergarten and first grade years?

(2) What were the differences in reading development, reading knowledge, and skills between English Language Learners (ELLs) and English Only Learners (EOLs) children in kindergarten and first grade years?

\section{$3 \quad$ Method}

\subsection{Data File and Samples}

Data used in this study came from the Early Childhood Longitudinal Study, Kindergarten Class of 1998-99 (ECLS-K). The analyses based on K- $8^{\text {th }}$ grade full sample data showing the use of ECLS-K, which is sponsored by the U.S. Department of Education and National Center for Education Statistics (NCES). The ECLS-K study selected a nationally representative sample of kindergartners in the fall of 1998 and followed these children through the end of the eighth grade. In the year 1998, more than 17,000 students started kindergarten. To better define the scope of this study, students who identified as having learning disabilities in kindergarten were not included. This study included a total sample of 14,873 students. 


\subsection{Independent Variable}

The independent variable of the study was the indicator of English language used at home. This indicator included two groups of students. Firstly, the ELL group was composed of students who did not speak English at home. Secondly, the EOL group was composed of students who spoke English at home.

\subsection{Dependent Variables}

The dependent variables include students' reading Item Response Theory (IRT) scale scores and reading proficiency scores. The IRT scale scores are assessments of students' academic performance in reading and are composed of different sets of test items with varying degrees of difficulty. IRT equates the different tests to a common vertical scale. The IRT scale scores provide unique functions that, allow the researchers to make comparisons of achievement across semesters.

The proficiency scores represent a progression of skills. In the kindergarten and first grade years, eight levels of reading proficiency conducted showed to evaluate students' reading development. Listed below are the eight proficiencies from the lowest to the highest.

Level 1: Letter recognition: identifying upper- and lower-case letters by name

Level 2: Beginning sounds: associating letters with sounds at the beginning of words

Level 3: Ending sounds: associating letters with sounds at the end of words

Level 4: Sight words: recognizing common "sight" words

Level 5: Comprehension of words in context: reading words in context

Level 6: Literal inference: making inferences using cues that are directly stated with key words in text (for example, recognizing the comparison being made in a simile)

Level 7: Extrapolation: identifying clues used to make inferences and using background knowledge combined with cues in a sentence to understand the use of homonyms

Level 8: Evaluation: demonstrating understanding of an author's craft (how does the author let you know...) and making connections between a problem in the narrative and similar life problems

\subsection{Weights}

The ECLS-K used a multistage probability sample design to select a nationally representative sample of children attending kindergarten in 1998-99. Based on the recommendation made by the National Center for Education Statistics (NCES), the eighth grade "direct child assessment" weight of $\mathrm{C} 1$ 7FC0 applied in this study so that the results were applicable to the norm (Torangeau et al., 2009). Educators can use the results to interpret children's performance in the population and help students improve reading learning outcomes.

\subsection{Analyses}

Descriptive analyses conducted for data quality checking, also provided references for further analyses. T-tests conducted tested the differences in reading IRT scores between two language groups.

\section{$4 \quad$ Results}

The descriptive analyses showed there were 7,247 (48.7\%) male students and 7,626 (51.3\%) female students. Twenty nine hundred and thirty-one (19.7\%) students came from "below poverty threshold" families, while 11,942 (80.3\%) children were from "at/above poverty threshold" families. There were $12,408(83.4 \%)$ children who spoke English at home and 2,077 (14\%) children who did not.

T-tests conducted to test for the differences in student reading performance between the two language groups. These evaluations were performed three times - once in the fall and spring semesters of kindergarten and finally during the spring of first grade. All significant tests had satisfactory power and all $\mathrm{t}$ values were significant $(p<0.001)$. This indicates that the language background had significant effects on students' reading performance. 


\subsection{Kindergarten - Fall Semester}

The average weighted kindergarteners' reading IRT scale score for all the students was 35.95 with a standard deviation of 9.90 and a range from 21.45 to 128.08 (see table 1). The mean score for the EOL group was 36.05 and the corresponding mean for the ELL group was 34.36. The t-test showed statistical significance, $[\mathrm{t}(173368)=-54.36, \mathrm{p}<.001]($ see table 2$)$.

The percentages of the overall-weighted kindergarteners that demonstrated reading proficiencies in the fall semester were $70 \%$ for letter recognition, $33 \%$ for beginning sounds, $19 \%$ for ending sounds, $4 \%$ for sight words, and only $2 \%$ for words in context. The EOL group of children had $71 \%$ for letter recognition, $34 \%$ for beginning sounds, $20 \%$ for ending sounds, $4 \%$ for sight words, and $2 \%$ for words in context. The ELL group of children showed $58 \%$ for letter recognition, $26 \%$ for beginning sounds, $15 \%$ for ending sounds, $4 \%$ for sight words, $3 \%$ word in context and $1 \%$ literal inference (see table 3 ).

\subsection{Kindergarten - Spring Semester}

The average weighted kindergarteners' reading IRT scale score for all the students was 47.45 with a standard deviation of 13.88 and a range from 22.73 to 156.85 (see table 1). The mean score for the EOL group was 47.67 and that of the ELL group was 44.93. The t-test showed statistical significance, $[\mathrm{t}(257070)=-80.07, \mathrm{p}<.001]$ (see table 2$)$.

The percentages of the overall-weighted kindergarteners who demonstrated reading proficiencies in the spring semester were $94 \%$ for letter recognition, $73 \%$ for beginning sounds, $54 \%$ for ending sounds, $18 \%$ for sight words, $7 \%$ for words in context, and $2 \%$ for literal inference. The EOL group of children had $95 \%$ for letter recognition, $74 \%$ for beginning sounds, $55 \%$ for ending sounds, $18 \%$ for sight words, $7 \%$ for words in context, and $2 \%$ for literal inference. The ELL group of children showed $89 \%$ for letter recognition, $62 \%$ for beginning sounds, $43 \%$ for ending sounds, $14 \%$ for sight words, $7 \%$ for words in context, $2 \%$ for literal inference, and $1 \%$ extrapolation (see table 3 ).

\subsection{First Grade}

The average weighted kindergarteners' reading IRT scale score for all the students was 79.99 with a standard deviation of 24.07 and a range from 27.92 to 184.05 . The mean score for the EOL group was 81.04 and that of the ELL group was 71.04. The t-test showed statistical significance, $[\mathrm{t}(385169)=$ $227.48, \mathrm{p}<.001]$ (see table 2).

The percentages of the overall-weighted first graders who demonstrated reading proficiencies in the spring semester were $98 \%$ for beginning sounds, $94 \%$ for ending sounds, $78 \%$ for sight words, $51 \%$ for words in context, $20 \%$ for literal inference, $7 \%$ for extrapolation, and $4 \%$ for evaluation. The EOL group of children had $98 \%$ for beginning sounds, $95 \%$ for ending sounds, $80 \%$ for sight words, $53 \%$ for words in context, $21 \%$ for literal inference, $7 \%$ for extrapolation, and $4 \%$ for evaluation. The ELL group of children showed $97 \%$ for beginning sounds, $90 \%$ for ending sounds, $65 \%$ for sight words, $38 \%$ for words in context, $13 \%$ for literal inference, $4 \%$ for extrapolation, and $2 \%$ for evaluation (see table 4 ).

\section{Discussion}

The ECLS-K kindergarten data file provides a unique opportunity to study children reading development during kindergarten and first grade years. In the year 1998, nearly 15,000 students were without learning disabilities who started the kindergarten year. Among those students, $14 \%$ were English Language Learners. Overall, children showed predictable growth in reading development as well as the progression from the lowest to the highest reading proficiencies.

Children's learning outcomes in reading performance and proficiencies have shown differences between the English-only learners (EOL) and English-language learner (ELL) groups. The EOL children did better however, than ELL children in development of reading IRT scale scores and reading proficiencies in all three rounds of assessments. The reading gap seemed to widen between the groups as the children finished the first grade (see figure 1).

During the fall of the kindergarten year, ELL children did not do well on the proficiencies of letter recognition and beginning sounds (see figure 2). In the spring of kindergarten, ELL students showed 
slower development on the proficiencies of beginning sounds and ending sounds (see figure 3 ). In the first grade, ELL students faced more challenges developing the competencies of sight words, word in context, and literal inference (see figure 4).

Therefore, this study has added to the large body of the existing literature on the crucial importance of developing ELL students' reading proficiency. Research studies have consistently found that the process of reading in a second language is essentially the same as reading in a first language (Peregoy \& Boyle, 2013). Both require the mastery of phonology, morphology, syntax, semantics, and pragmatics, and the adoption of background knowledge. Yet, the task of developing second language literacy is knowingly more difficult and complex.

Researchers in literacy assert that only about half of what people understand when they read in any language has to do with knowing that language's vocabulary and its grammar. The other half involves factors such as background knowledge about the topic, knowledge of a genre, strategies for guessing and working with uncertainty, and strategies for identifying cognates and other textual clues (illustrations, subtitles, etc.).

According to Peregoy and Boyle (2013), there are two most important factors influencing second language reading comprehension: second language proficiency and background knowledge pertinent to reading the text. ELL students may experience reading difficulties due to insufficient English language proficiency and prior knowledge of the topic. This knowledge is indispensable for teachers working with ELLs striving to increase reading proficiency of English learners.

To promote reading development teachers need to provide reading materials on the content familiar to ELLs and build a background before reading, which can greatly help offset the reading comprehension difficulties stemming from limited second language proficiency. In addition, various teaching techniques are highly effective in ESL reading instruction. Including, augmenting textbook readings with authentic materials, introducing new readings with interactivity to motivate and ease the comprehension process, providing activities to help students identify, to reproduce, or to interpret a text's information and messages, comparing L1 and L2 texts to uncover similarities and differences and build on ELL students' L1, etc. Explicitly teaching ELLs reading strategies has also been frequently used by reading teachers to enhance ELLs reading proficiency, such as, using titles and illustrations to understand a passage, skimming for an overview, scanning for specific information, guessing or predicting meaning, applying background knowledge about the text's genre and context.

Young ELLs benefited more when the student participated in kindergarten programs. The children showed higher reading performance through the end of the kindergarten and first grade years. It is critical to provide a rich reading environment for ELL children during the early elementary school years. ELL students need to read more in order to improve reading proficiencies. In addition, having well trained ELL teachers to teach young children is a necessity for this country. The results of this study indicate that ELL training for teachers throughout each school district in every state is highly recommended.

Reading development, to ELL students, is not simply a task to read in the target language, to speak, write, and understand the target culture, but also a fundamental basis for learning academic content knowledge. It is important for teachers to view reading as a holistic, multi-literacy endeavor that is critical for the broader educational goals of ELLs. Given the high proportion of ELLs accounting for the majority of K-12 enrollment growth and the increased diversity of students in U.S. schools, preparation is essential for all teachers of ELL students' reading development, among the many other needs of these students.

\section{$6 \quad$ Future Studies}

Educators can provide effective teaching to help ELLs focus on the language skills students are struggling with in kindergarten and first grade. For example, in the spring of the first grade, the ELL group had lagged behind in "sight words" and "word in context." Teachers could use the findings to help ELL children to improve in these two areas. Early intervention in reading will help ELL students to catch up to the leaning pace and provide them with the opportunities to maximize development in reading. In addition, it is important to continue tracking this group of students' reading development to 
understand how well students mastered the higher levels of reading proficiencies compared to the EOL counterparts. The results will be beneficial for improving future teaching of ELL students.

\section{References}

1. Aud, S., Wilkinson-Flicker, S., Kristapovich, P., Rathbun, A., Wang, X., and Zhang, J. (2013). The Condition of Education 2013 (NCES 2013-037). U.S. Department of Education, National Center for Education Statistics. Washington, DC.

2. Clark, E. V. (1995). The lexicon in acquisition (Vol. 65). Cambridge University Press.

3. Cummns, J. (1991). Interdependence of first and second language proficiency in bilingual children. In E. Bialystok (Ed.), Language processing in bilingual children (pp. 70-89). New York: Cambridge University Press.

4. de Villiers, P.A., \& de Villiers, J.G. (1979). Early language. Cambridge, MA: Harvard University Press.

5. Ehri, L. C. (2003). Systematic Phonics Instruction: Findings of the National Reading Panel.

6. Espinosa, L. M. (2008). Challenging common myths about young English language learners. FCD Policy Brief, Advancing PK-3, (8).

7. Fry, R. (2007). How Far behind in Math and Reading Are English Language Learners? Report. Pew Hispanic Center.

8. Gelman, S. A., \& Kalish, C. W. (2006). Conceptual development. Handbook of child psychology.

9. Grossen, B. (1997). 30 years of research: What we now know about how children learn to read.

10.Hammer, C. S., Lawrence, F. R., \& Miccio, A. W. (2007). Bilingual children's language abilities and early reading outcomes in Head Start and kindergarten. Language, Speech, and Hearing Services in Schools, 38(3), $237-248$.

11.Kena, G., Musu-Gillette, L., Robinson, J., Wang, X., Rathbun, A., Zhang, J. \& Velez, E. D. V. (2015). The Condition of Education 2015. NCES 2015-144. National Center for Education Statistics.

12.Krashen, S. D. (2004). The power of reading: Insights from the research (2nd ed.). Portsmouth, NH: Heinemann.

13.Lake, V. E., \& Pappamihiel, E. (2003). Effective practices and principles to support English language learners in the early childhood classroom. Childhood Education, 79, 200-204.

14.McLaughlin, B. (1984). Second-language acquisition in childhood: Vol. 1. Preschool children (2nd ed.). Hillsdale, NJ.

15.National Center for Education Statistics. (2014). The Nation's Report Card Mathematics and Reading 2013 : Trends in 4th- and 8th-grade NAEP mathematics and reading achievement-level results, by status as English language learners (ELL). Institute of Education Sciences, U.S. Department of Education. Retrieved from http://www. nationsreportcard.gov/reading_math_2013/\#/studentgroups.

16.National Institutes of Health. (2000). Report of the National Reading Panel: Teaching children to read (NIH Publication No. 00-4769. Retrieved September, 14, 2007.

17.National Reading Panel. (2000). Teaching children to read: An evidence-based assessment of the scientific research literature on reading and its implications for reading instruction. Washington, DC: National Institute of Child Health and Human Development.

18.Perie, M., Grigg, W., \& Donahue, P. (2005). The Nation's Report Card [TM]: Reading, 2005. NCES 2006-451. National Center for Education Statistics.

19.Moats, L. (2001). Overcoming the language gap. American Educator, 25(2), 4-9.

20.Peregoy, S., \& Boyle, O. (2013). Reading and writing, and learning in ESL: A resource book for teaching K-12 English learners (6th ed.). NJ: Pearson.

21.Rack, J. P., Snowling, M. J., \& Olson, R. K. (1992). The nonword reading deficit in developmental dyslexia: A review. Reading Research Quarterly, 29-53.

22.Santos de Barona, M., \& Barona, A. (1991). The assessment of culturally and linguistically different preschoolers. Early Childhood Research Quarterly, 6, 363-376.

23.Se'ne'chal, M., LeFevre, J., Thomas, E., \& Daley, K. (1998). Differential effects of home literacy experiences on the development of oral and written language. Reading Research Quarterly, 33, 96-116.

24.Slavin, R. E., \& Cheung, A. (2004). How do English language learners learn to read? Educational Leadership, $61(6), 52-57$. 
25.Share, D. L., Jorm, A. F., Maclean, R., \& Matthews, R. (1984). Sources of individual differences in reading acquisition. Journal of educational Psychology, 76(6), 1309.

26.Tourangeau, K., Nord, C., Lê, T., Sorongon, A. G., \& Najarian, M. (2009). Early Childhood Longitudinal Study, Kindergarten Class of 1998-99 (ECLS-K): Combined User's Manual for the ECLS-K Eighth-Grade and K-8 Full Sample Data Files and Electronic Codebooks. NCES 2009-004. National Center for Education Statistics.

27.Zill, N., Resnick, G., Kim, K., O'Donnell, K., Sorongon, A., McKey, R. H. \& D'Elio, M. A. (2003). Head Start FACES 2000: A Whole-Child Perspective on Program Performance. Fourth Progress Report.

\section{Appendix. A}

Table 1. Reading IRT scores by language group in kindergarten and first grade

\begin{tabular}{l|l|r|r|r}
\hline Group & & K-Fall & K-Spring & 1st -Spring \\
\hline \multirow{4}{*}{ ELL } & Mean & 34.36 & 44.93 & 71.04 \\
\cline { 2 - 5 } & SD & 12.26 & 15.75 & 22.71 \\
\cline { 2 - 5 } & Min & 21.51 & 24.62 & 31.63 \\
\cline { 2 - 5 } & Max & 121.86 & 156.85 & 171.80 \\
\cline { 2 - 5 } & Range & 100.35 & 132.23 & 140.17 \\
\hline \multirow{4}{*}{ EOL } & Mean & 36.05 & 47.67 & 81.04 \\
\cline { 2 - 5 } & SD & 9.73 & 13.68 & 24.01 \\
\cline { 2 - 5 } & Min & 21.45 & 22.73 & 27.92 \\
\cline { 2 - 5 } & Max & 128.08 & 156.85 & 184.05 \\
\cline { 2 - 5 } & Range & 106.63 & 134.12 & 156.13 \\
\hline \hline All & Mean & 35.95 & 47.45 & 79.99 \\
\cline { 2 - 5 } & SD & 9.90 & 13.88 & 24.07 \\
\cline { 2 - 5 } & Min & 21.45 & 22.73 & 27.92 \\
\cline { 2 - 5 } & Max & 128.08 & 156.85 & 184.05 \\
\cline { 2 - 5 } & Range & 106.63 & 134.12 & 156.13 \\
\hline
\end{tabular}

Table 2. T-Test of reading IRT scores by language group in kindergarten and first grade

\begin{tabular}{|c|c|c|c|c|c|c|c|c|}
\hline & & Group & & & & & & \\
\hline & ELL & & $\mathrm{EOL}$ & & \multicolumn{3}{|c|}{ 95\% CI for Mean Difference } & \\
\hline & $\mathrm{M}$ & $\mathrm{SD}$ & $\mathrm{M}$ & $\mathrm{SD}$ & & & $\mathrm{t}$ & $\mathrm{df}$ \\
\hline K-Fall & 34.36 & 12.26 & 36.05 & 9.73 & -1.76 & -1.63 & $-54.36^{* * *}$ & 173368 \\
\hline K-Spring & 44.93 & 15.75 & 47.67 & 13.68 & -2.80 & -2.67 & $-80.07^{* * *}$ & 257070 \\
\hline First Grade & 71.04 & 22.71 & 81.04 & 24.01 & -10.08 & -9.91 & $-227.48^{* * *}$ & 385169 \\
\hline
\end{tabular}

Note. ${ }^{* * *} P<.001$.

Table 3. Kindergarten reading proficiencies by language group

\begin{tabular}{l|l|l|l|l|l|l|l}
\hline Semester & $\begin{array}{l}\text { Letter } \\
\text { Recog- } \\
\text { nition }\end{array}$ & $\begin{array}{l}\text { Beginning } \\
\text { Sounds }\end{array}$ & $\begin{array}{l}\text { Ending } \\
\text { Sounds }\end{array}$ & $\begin{array}{l}\text { Sight } \\
\text { Words }\end{array}$ & $\begin{array}{l}\text { Word in } \\
\text { Context }\end{array}$ & $\begin{array}{l}\text { Literal } \\
\text { Inference }\end{array}$ & $\begin{array}{l}\text { Extrapo- } \\
\text { lation }\end{array}$ \\
\hline K-Fall & & & & & & & \\
\hline ELL & $58 \%$ & $26 \%$ & $15 \%$ & $4 \%$ & $3 \%$ & $1 \%$ & $0 \%$ \\
\hline EOL & $71 \%$ & $34 \%$ & $20 \%$ & $4 \%$ & $2 \%$ & $0 \%$ & $0 \%$ \\
\hline All & $70 \%$ & $33 \%$ & $19 \%$ & $4 \%$ & $2 \%$ & $0 \%$ & $0 \%$ \\
\hline K-Spring & & & & & & & $2 \%$ \\
\hline ELL & $89 \%$ & $62 \%$ & $43 \%$ & $14 \%$ & $7 \%$ & & $1 \%$ \\
\hline
\end{tabular}




\begin{tabular}{l|l|l|l|l|l|l|l}
\hline EOL & $95 \%$ & $74 \%$ & $55 \%$ & $18 \%$ & $7 \%$ & $2 \%$ & $0 \%$ \\
\hline All & $94 \%$ & $73 \%$ & $54 \%$ & $18 \%$ & $7 \%$ & $2 \%$ & $0 \%$ \\
\hline
\end{tabular}

Table 4. First grade reading proficiencies by language group

\begin{tabular}{l|l|l|l|l|l|l|l}
\hline $\begin{array}{l}1 \text { st } \\
\text { Grade }\end{array}$ & $\begin{array}{l}\text { Beginning } \\
\text { Sounds }\end{array}$ & $\begin{array}{l}\text { Ending } \\
\text { Sounds }\end{array}$ & $\begin{array}{l}\text { Sight } \\
\text { Words }\end{array}$ & $\begin{array}{l}\text { Word in } \\
\text { Context }\end{array}$ & $\begin{array}{l}\text { Literal } \\
\text { Inference }\end{array}$ & Extrapolation & Evaluation \\
\hline ELL & $97 \%$ & $90 \%$ & $65 \%$ & $38 \%$ & $13 \%$ & $4 \%$ & $2 \%$ \\
\hline EOL & $98 \%$ & $95 \%$ & $80 \%$ & $53 \%$ & $21 \%$ & $7 \%$ & $4 \%$ \\
\hline All & $98 \%$ & $94 \%$ & $78 \%$ & $51 \%$ & $20 \%$ & $7 \%$ & $4 \%$ \\
\hline
\end{tabular}

\section{Appendix. B}

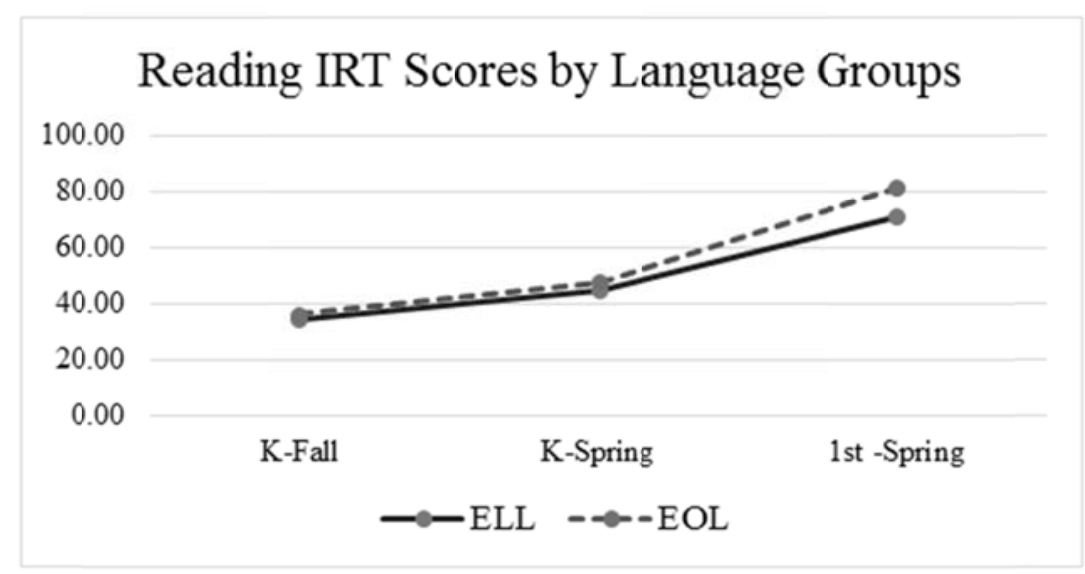

Figure 1. Reading IRT scores changed between kindergarten and first grade

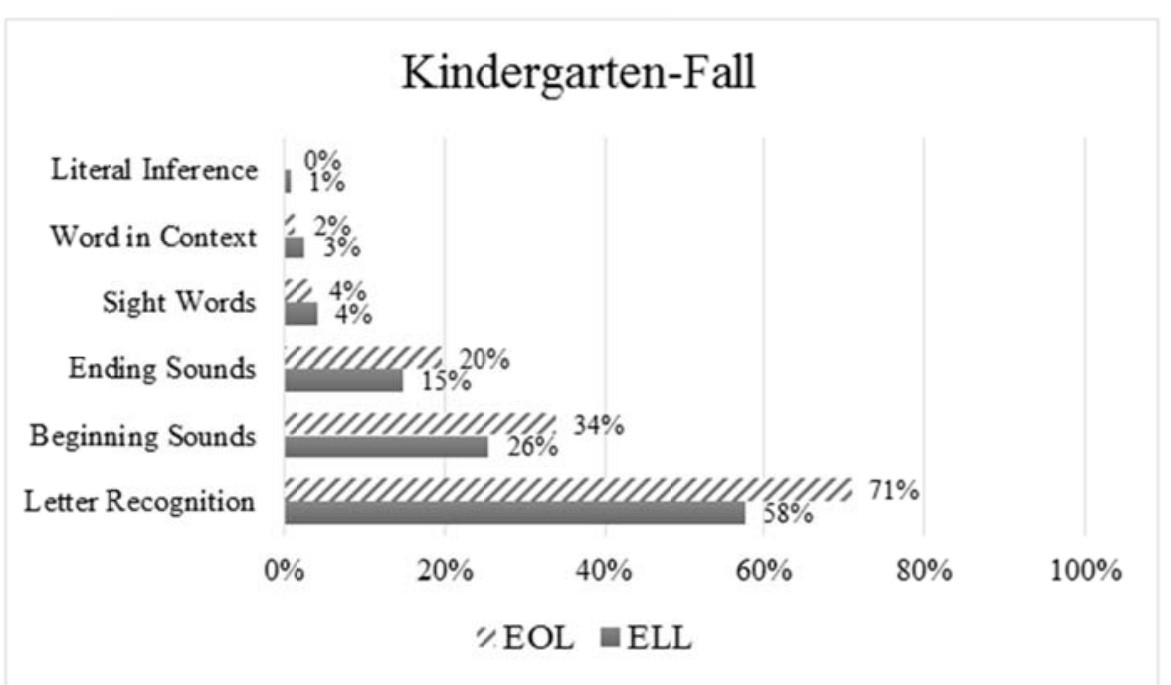

Figure 2. Reading proficiencies mastered in the fall of kindergarten 


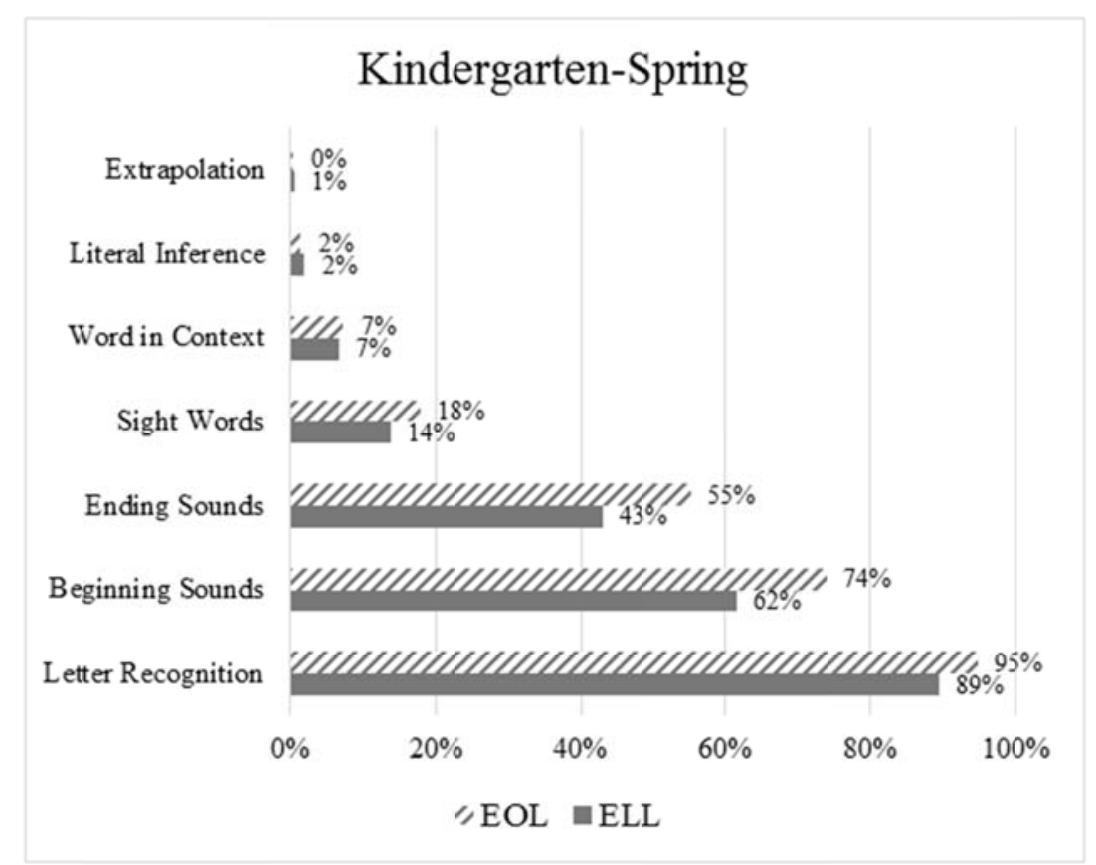

Figure 3. Reading proficiencies mastered in the spring of kindergarten

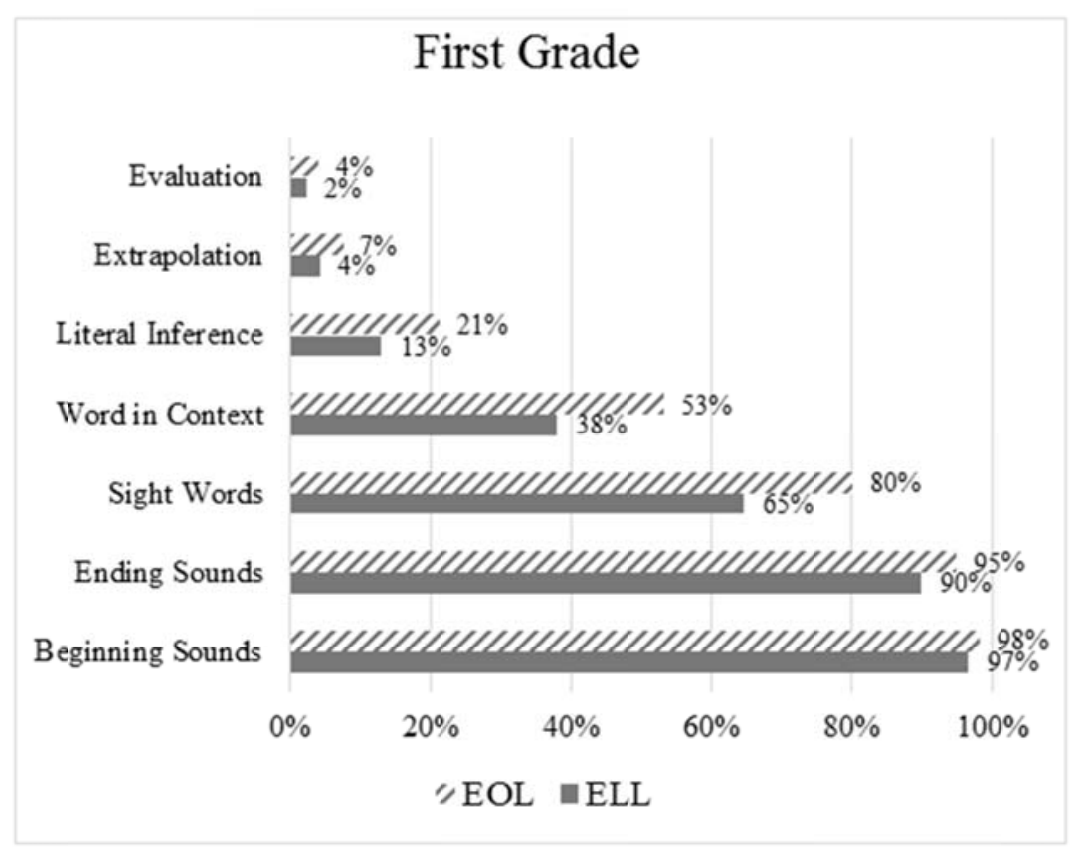

Figure 4. Reading proficiencies mastered in first grade 